\title{
PENGETAHUAN DAN SIKAP SISWA USAHA KESEHATAN SEKOLAH TENTANG BULLYING DI SMP X DI KOTA SAMARINDA
}

\author{
Fransiska Keron Ola \\ Program Studi DIII Keperawatan STIKES Dirgahayu Samarinda \\ Jl. Pasundan No 54 telp/Faks (0541) 748335 \\ cerollao@gmail.com
}

\begin{abstract}
ABSTRAK
Tujuan: Bullying adalah perilaku yang berlebihan, monoton, dan merusak, berdasarkan pada kekuatan siswa. Ada banyak bentuk bullying seperti memanggil nama, memukul atau mengancam orang lain dan menyebarkan desas-desus palsu. Dengan demikian, bullying menciptakan hambatan untuk belajar dengan hasil negatif pada siswa dan institusi. Siswa dapat lebih diburu dan bertindak beberapa kali sesuai dengan situasi. Metode: Penulis menggunakan metode analisis deskriptif, yang menjelaskan data yang diperoleh dengan menggunakan perhitungan persentase atau yang biasa disebut frekuensi relatif. Tujuan penelitian: Tujuan dari penelitian ini adalah untuk menentukan tingkat pengetahuan dan sikap siswa terhadap bullying di SMP X Kota Samarinda. Penelitian ini di lakukan pada Agustus 2018 dan data dianalisis dengan persentase. Hasil: Karakteristik responden adalah siswa yang menggikuti organisasi usaha kesehatan sekolah di Kota Samarinda yang tergabung dalam organisasi usaha kesehatan sekolah. Perhitungan pengetahuan perilaku bullying baik dengan persentase $100 \%$ dan sikap siswa terhadap bullying dengan presentase 93,33\% serta hasil uji korelasi Spearman Rank antara pengetahuan bullying dan sikap bullying dengan nilai $\rho=0.357$ dan dibandingkan dengan tabel rho dengan tingkat kesalahan $5 \%(\rho=0,05)$, tingkat kepercayaan $95 \%$ dan $\mathrm{N}=30$, maka harga $(\rho)=0,364$. Kesimpulan: Tidak ada hubungan antara pengetahuan perilaku bullying terhadap sikap siswa tentang bullying.
\end{abstract}

Kata kunci: Pengetahuan, Sikap, Bullying

\section{PENDAHULUAN}

Menurut Pusat Keamanan Sekolah Nasional, bullying adalah masalah yang paling abadi dan diremehkan di sekolahsekolah AS. Dalam sampel perwakilan nasional, hampir $30 \%$ siswa yang disurvei melaporkan terlibat dalam bullying dalam kondisi saat ini, baik sebagai pelaku atau korban (Smokowski, Cotter, Robertson, \& Guo, 2013).

Saat ini, bullying dianggap sebagai masalah kesehatan mental dengan konsekuensi sosial dan psikologis yang parah. Peran sekolah dalam menghasilkan fenomena bullying sangat kompleks dan sekolah memiliki potensi untuk bertindak sebagai agen kontrol. Ada kemungkinan bahwa sekolah dapat didasarkan pada pengalaman yang mereka tawarkan kepada siswa, baik mengurangi atau meningkatkan risiko yang terkait dengan karakteristik dan latar belakang anak (Papacosta \& Paradeisioti, n.d.).

Akibatnya, seorang individu dapat memainkan peran sebagai pelaku bullying dalam satu saat dan mungkin menjadi korban dalam situasi lain tergantung pada kekuatan yang ditampilkan. Dengan berdiri, dapat mengalami penyalahgunaan, kecemasan, dan depresi. Untuk memastikan keamanan sekolah dan mempromosikan sikap positif dalam skenario sekolah, kebijakan anti-gelombang dapat diperkenalkan untuk mencegah intimidasi. Sekolah memiliki tanggung jawab etis dan hukum untuk menciptakan lingkungan sekolah yang aman dan mendukung dengan membenarkan dampak agresi, penindasan, dan memastikan lingkungan belajar-mengajar 
yang sehat. Indikasi prevalensi bullying dan viktimisasi di seluruh dunia dapat diambil dari sejumlah besar studi berbasis masyarakat. (Kljakovic et al., 2015). Pernyataan masalah dalam penelitian ini adalah "Pengetahuan dan Sikap siswa organisasi usaha kesehatan sekolah terhadap Bullying di sekolah menengah pertama di kota Samarinda". Penelitian ini bertujuan untuk mengetahui "Pengetahuan dan Sikap Organisasi usaha kesehatan sekolah terhadap bullying di Sekolah Menengah pertama di kota Samarinda.

\section{METODE}

Penelitian ini menggunakan jenis penelitian deskriptif, yang didasarkan pada tujuannya untuk melihat gambaran dan menganalisis faktor-faktor yang menyebabkan munculnya fenomena intimidasi pada siswa sekolah menengah pertama. Penelitian ini juga diklasifikasikan sebagai penelitian kuantitatif jika didasarkan pada proses yang digunakan untuk mendapatkan jawaban dengan menghitung variasi dalam variabel bullying menggunakan statistik. Subjek penelitian adalah 30 siswa di sekolah menengah pertama yang mengikuti organisasi usaha kesehatan sekolah di Kota Samarinda, Kalimantan Timur, Indonesia. Pengukuran sikap terhadap perilaku bullying pada remaja menggunakan survei kuesioner Bullying untuk mengukur pengetahuan tentang perilaku bullying dan sikap. Semua data yang telah dikumpulkan dari sumber penelitian dibahas oleh penulis menggunakan metode analisis deskriptif, yaitu menjelaskan data yang diperoleh dengan menggunakan perhitungan dari persentase atau biasa disebut frekuensi relatif.

\section{HASIL}

Responden siswa yang menggikuti organisasi usaha kesehatan sekolah di kota Samarinda. Jumlah 30 orang dengan usia responden bervariasi antara 12 tahun, 13 tahun dan 14 tahun. Berdasarkan distribusi grafik batang di atas, ada paling banyak 13 tahun dan 14 tahun dengan $46,66 \%$ pada usia yang sama. Responden di atas adalah remaja. Menurut teori perkembangan menurut Erikson dan Sigmund Freud 'Tahap kelima adalah tahap remaja (remaja), yang dimulai saat pubertas dan berakhir pada usia 18 atau 20 tahun. Adolescence (adolescence) menandai kecenderungan identitas Identity Confusion. Pada usia remaja di mana ada perubahan dari usia anak-anak menjadi remaja, remaja dengan menunjukkan identitas mereka dan kadang-kadang tampak ekstrem dengan tindakan memukul, menendang, mendorong, menggunakan bahasa kasar, memanipulasi pertemanan yang sering dilakukan oleh usia yang lebih tua dan mengganggu mereka usia yang lebih muda.

a. Distribusi karakteristik responden berdasarkan jenis kelamin di Organisasi Usaha Kesehatan Sekolah Menengah Pertama di Kota Samarinda

Responden terdiri dari siswa Usaha Kesehatan Sekolah di Kota Samarinda berjumlah 30 orang dengan jenis kelamin laki-laki dan perempuan dengan persentase $93,33 \%$ jenis kelamin perempuan dan $6,66 \%$ jenis kelamin lakilaki. Menurut data dari pusat statistik Indonesia 2019, jumlah laki-laki adalah 134,7 juta dan 133,4 juta adalah perempuan. Sebagian besar responden adalah perempuan dengan 28 orang dengan persentase $93,33 \%$ dan laki-laki dengan 2 orang dengan persentase $6,66 \%$. Responden wanita lebih dominan dan berbanding terbalik dengan bullying yang sering dilakukan oleh pria. Kejadian bullying menurut tingkat intimidasi seks 
dan tingkat viktimisasi juga tampak berbeda berdasarkan jenis kelamin. Secara umum, intimidasi tradisional tampaknya lebih umum pada sampel wanita pria (Barboza, Schiamberg, Oehmke, Korzeniewski, Post \& Heraux, 2009; Li, 2006). Juga sering ditemukan bahwa meskipun pelaku intimidasi paling sering adalah anak laki-laki, anak lakilaki dan perempuan cenderung menjadi korban (Rodkin \& Berger, 2008). Namun, beberapa orang berpendapat bahwa mereka berpendapat bahwa perbedaan ini mungkin karena pria tertinggal dalam agresi fisik yang lebih jelas, sementara wanita terlibat dalam agresi relasional, yang kurang dapat diamati (Craig, 1998; Olweus, 1991).

Distribusi karakteristik responden berdasarkan kelas di organisasi Usaha Kesehatan Sekolah di kota Samarinda.

Perbedaan responden kelas dari kelas VII, VIII dan IX. Berdasarkan distribusi jumlah responden tertinggi di kelas IX dengan 19 orang dengan persentase 63,33\%. Dalam Kegiatan Kesehatan Sekolah, sebagian besar anggota adalah siswa di tingkat akhir karena, di sekolah menengah pertama, siswa dan siswa di tingkat terakhir akan menjadi panutan bagi siswa dan siswa yang memiliki tingkat lebih rendah atau kelas yang lebih muda.

Di usia sekolah, beberapa waktu dihabiskan di sekolah sehingga minat dan komitmen antar siswa sangat kuat di mana emosi yang saling terkait saling tergantung sehingga mereka menunjukkan satu sama lain siapa dirinya.

a. Kekerasan yang terjadi di lingkungan sekolah dilakukan oleh individu antara siswa, guru dan anggota pendidik. Kekerasan ini memiliki efek besar seperti kebencian dendam atas perasaan tidak aman, balas dendam, benci, takut, dan marah. Teman sekelas saling membenci, teman sekelas membenci teman sekelas, siswa membenci guru, pendidik saling membenci. b. Organisasi usaha kesehatan sekolah adalah salah satu upaya kesehatan utama yang dilakukan oleh Puskesmas dan juga bisnis kesehatan masyarakat yang dilaksanakan di sekolah dengan siswa dan lingkungan sekolah sebagai target utama.

c. Sebuah. Pengetahuan tentang Perilaku bullying.

d. Distribusi pengetahuan tentang perilaku bullying di kalangan siswa Sekolah Menengah pertama di Kota Samarinda.

e. Distribusi menunjukkan bahwa 30 responden memiliki pengetahuan yang baik tentang perilaku bullying dengan persentase $100 \%$, yang hampir semua responden adalah anggota Organisasi Kesehatan Sekolah memiliki pengetahuan yang baik tentang perilaku bullying. Menurut Undang-Undang No. 2 tahun 1989, peran pelaksana organisasi usaha kesehatan sekolah adalah memberi contoh. Pelaksana Organisasi Usaha Kesehatan sekolah yang bertindak sebagai pendidik. Peran organisasi usaha kesehatan siswa menerapkan guru sebagai pengontrol dalam mengawasi kegiatan pendidikan kesehatan. Sesuai dengan situasi mengenai peran anggota Usaha kesehatan sekolah sebagai panutan, pengendali, pengawas di mana anggota organisasi kesehatan siswa memiliki $100 \%$ pengetahuan yang baik tentang perilaku bullying karena siswa anggota organisasi kesehatan dapat menjadi panutan di antara sesama siswa dalam perilaku mereka, sebagai pendidik di antara siswa guru sebagai pendidik memberikan pendidikan tentang perilaku yang baik dan sopan sehingga tercermin dalam setiap perilaku anggota organisasi Usaha kesehatan sekolah dalam bergaul dengan sesama siswa.

\section{f. Distribusi sikap}

Distribusi menunjukkan data bahwa sebanyak 28 responden memiliki sikap bullying yang baik dengan persentase $93,33 \%$ dan 2 responden memiliki pengetahuan tentang perilaku 
bullying yang cukup dengan persentase 6,66\%. Menurut Tarnawan (2007), tujuan dari Usaha Kesehatan Sekolah adalah untuk meningkatkan kemampuan hidup sehat siswa dalam lingkungan yang sehat, sehingga siswa dapat belajar, tumbuh dan berkembang secara harmonis dan optimal, menjadi sumber daya manusia yang berkualitas.

Di usia sekolah, beberapa waktu dihabiskan di sekolah sehingga minat dan komitmen antar siswa sangat kuat di mana emosi yang saling terkait saling tergantung sehingga mereka menunjukkan satu sama lain siapa dirinya. Membangun komunikasi terbuka antara guru, orang tua, dan siswa. Orang tua diharapkan berteman dengan anak-anak mereka dan berkomunikasi dengan sekolah, guru sebagai mitra dengan siswa diharapkan memahami dan menempatkan setiap siswa, sementara siswa tidak tahu tempat yang tepat untuk mengeluh.

Dengan berkomunikasi, penting untuk menemukan solusi dan solusi untuk kasus kekerasan, dan kemauan semua pihak yang terkait dengan siswa, guru, orang tua untuk berkomunikasi secara terbuka dan jujur untuk menyelesaikan kasus-kasus bullying.

\section{PEMBAHASAN}

Analisis hubungan antara perilaku bullying dan sikap siswa organisasi Usaha Kesehatan Sekolah di Kota Samarinda.

Menganalisis hubungan antara pengetahuan tentang perilaku bullying dan sikap dari Sekolah Menengah Pertama di Kota Samarinda dilakukan dengan menggunakan uji korelasi Spearman Rank. Hasil uji korelasi Spearman Rank antara perilaku bullying dengan sikap bullying ditujukan pada koefisien korelasi $(\rho)=0,357$ dan dibandingkan dengan tabel rho dengan tingkat kesalahan yang ditetapkan sebesar
$5 \%(\rho=0,05)$, tingkat kepercayaan $95 \%$ dan $\mathrm{N}=30$, maka harga $(\rho)=0,364$. Dianalisa dari perhitungan harga $r$ hitung lebih kecil dari $r$ tabel ( $r$ Hitung $>(\rho)$ tabel dengan hasil $0,357<0,364)$, sehingga hipotesis ditolak dan hipotesis alternatif diterima. Jadi, sebagai kesimpulan, tidak ada hubungan antara pengetahuan perilaku bullying dan sikap bullying khususnya siswa dan siswi yang menggikuti organisasi usaha kesehatan sekolah di Sekolah Menengah Pertama di Kota Samarinda.

Hasil uji korelasi ini menolak hipotesis yang dibuat. Jadi, Ho ditolak dan $\mathrm{Ha}$ diterima karena tidak ada hubungan yang berarti antara pengetahuan perilaku bullying dan sikap bullying. Ini berarti pengetahuan tentang perilaku bullying siswa Sekolah Menengah Pertama di Kota Samarinda sangat baik karena anggota organisasi Usaha Kesehatan Sekolah bertindak sebagai panutan, pelaksana, dan pendidik.

\section{KESIMPULAN}

Berdasarkan hasil analisis dan diskusi yang diuraikan, kesimpulan dapat ditarik:

1. Pengetahuan tentang perilaku bullying yang baik pada siswa sekolah menengah pertama di organisasi usaha kesehatan sekolah di Kota Samarinda.

2. Sikap Bullying baik di antara siswa yang tergabung dalam organisasi usaha kesehatan sekolah di Kota Samarinda.

\section{UCAPAN TERIMA KASIH}

1. Stikes Dirgahayu Samarinda

2. Sekolah menengah pertama di SMP $\mathrm{X}$ Samarinda 


\section{DAFTAR PUSTAKA}

Kljakovic, M., Hunt, C., Jose, P. E., \& Zealand, N. (2015). Incidence of Bullying and Victimisation among Adolescents in New Zealand, 44(2).

Papacosta, E. S., \& Paradeisioti, A. (n.d.). International Journal of Mental Health Promotion Bullying phenomenon and preventive programs in Cyprus' $\mathrm{s}$ school system, (June 2014), 37-41. https://doi.org/10.1080/14623730.2 014.888894

Smokowski, P. R., Cotter, K. L., Robertson, C., \& Guo, S. (2013).

Correlates of Bullying Victimization and School Hassles in Rural Youth, 2013.

Darney Christine, Howcroft Greg, Stroud Louise. (2013). The Impact That Bullying At School Has On An Individual's Self-Esteem During Young Adulhhood, International Journal Of Education and Research, Vol. 1 No. 8 August

Donegan Richard. (2012). Bullying and Cyberbullying: History, Statistics, Law, Prevention and Analysis. The Elon journal of Undergraduate Research in Communications. Vol. 3, No. 1. Spring

Seixas S., Raquel, Coelho J., Pinto \& Fischer-Nicolas G., (2013). Bullies, Victims and Bully-Victims, Impact on Health Profile, Educacao, Sociedade \& Culturas, no 38, 53-75 International Journal of Violence School. (2010). Prevalence of Bullying Among Cyprus Elementary and High School Studentas. Stavrinides Panayiotis, University of Cyprus

Hymel Shelley and Swearer Susan M., (2015). Four Decades of Research on School Bullying. American Psychological Association 0003-
066X/15/\$12.00. Vol. 70, No. 4293. May-June

Australian Government Department of Health and Ageing Under the Youth Mental Health Initiative Program. Bullying and Cyber Bullying. Headspace National Youth Mentah Health Foundation

Nielsen Skyt H., \& Simonsen M., (2012). The Effects of Bullying in Elementary School. Discussionpapeseries, IZA DP No. 6718, July

Jan Afroz MS (2015). Bullying In Elementary Schools: Its Causes and Effects on Students. Journal of Education and Practice www.iiste.org ISSN 2222-1735 (Paper) ISSN 2222-288X (Online). Vol. 6, No. 19

Ken R., Wolke D., Copeland W., E., Angold A., Costello E., J., (2013). Bullying in schools and its relation to parenting and family life. New Zealand Journal of Psychology Vol. 44 No. 2, September. Published On August 19, doi: 10. 1177/0956797613481608.

MS., Afroz Jan. (2015). Bullying in Elementary Schools: Its Causes and Effects on Students. Journal of Education and Practice www.iiste.org ISSN 2222-1735 (Paper) ISSN 2222-288X (Online). Vol.6, No.19

Susan M., Swearer. (2015). Four Decades of Research on School Bullying. American Psychological Association 0003-066X/15/12.00 Vol. 70, No.4, 293-299)

Brian P., Gendron, Kirk R., Williams \& Nancy G., Guerra. (2011). An 
Jurnal Keperawatan Dirgahayu

Volume 2, Nomor 1, Maret 2020

EISSN: 2685-3086

Analysis of Bullying Among

Students Within Schools:

Estimating the Effects of Individual

Normative Beliefs, Self- Esteem, and School Climate, Journal of School Violence, 10:150-164, 2011 (Journal of Adolescent Health 53 (2013) S1-S3 Bullying and Suicide: A Public Health Approach.ELSEVIER 